\title{
Article
}

\section{Combining Raman Spectroscopy, DFT Calculations, and Atomic Force Microscopy in the Study of Clinker Materials}

\author{
Vlasta Mohaček-Grošev $^{1, *(1)}$, Marija Đuroković $^{2}$ and Aleksandar Maksimović ${ }^{1}$ \\ 1 Centre of Excellence for Advanced Materials and Sensing Devices, Ruđer Bošković Institute, Bijenička Cesta \\ 54, 10000 Zagreb, Croatia; Aleksandar.Maksimovic@irb.hr \\ 2 Institut IGH d.d., Janka Rakuše 1, 10000 Zagreb, Croatia; marija.djurokovic@igh.hr \\ * Correspondence: mohacek@irb.hr
}

Citation: Mohaček-Grošev, V.;

Đuroković, M.; Maksimović, A

Combining Raman Spectroscopy, DFT

Calculations, and Atomic Force

Microscopy in the Study of Clinker

Materials. Materials 2021, 14, 3648 .

https://doi.org/10.3390/ma14133648

Academic Editor: Lizhi Sun

Received: 21 May 2021

Accepted: 24 June 2021

Published: 30 June 2021

Publisher's Note: MDPI stays neutral with regard to jurisdictional claims in published maps and institutional affiliations.

Copyright: (c) 2021 by the authors. Licensee MDPI, Basel, Switzerland. This article is an open access article distributed under the terms and conditions of the Creative Commons Attribution (CC BY) license (https:// creativecommons.org/licenses/by/ $4.0 /)$.

\begin{abstract}
Raman spectroscopy and Raman mapping analysis, combined with density functional theory calculations were applied to the problem of differentiating similar clinker materials such as alite and belite. The Portland cement clinker 217 (further: clinker) was analysed using colocalised Raman mapping and atomic force microscopy mapping, which provided both spatial and chemical information simultaneously. The main constituents found in the clinker were alite, belite, portlandite, amorphous calcium carbonate, and gypsum. Since phonon bands of alite and belite greatly overlap, and their distinction is important for the hydration process during cement setting, we provided the calculated phonon density of states for alite $\mathrm{Ca}_{3} \mathrm{SiO}_{5}(<\mathrm{M}>P c$ structure $)$ and belite $\mathrm{Ca}_{2} \mathrm{SiO}_{4}\left(\beta P 2_{1} / n\right.$ structure) here for the first time. Both calculated phonon densities have similar distribution of phonon modes, with a gap between 560 and $810 \mathrm{~cm}^{-1}$. A comparison of the calculated phonon frequencies for $\mathrm{Ca}_{3} \mathrm{SiO}_{5}$ and $\mathrm{Ca}_{2} \mathrm{SiO}_{4}$ shows that the lowest calculated phonon frequency of $\beta-\mathrm{Ca}_{2} \mathrm{SiO}_{4}$ lies at $102 \mathrm{~cm}^{-1}$, while for $<M>P c$ alite the lowest phonon frequency is predicted at $27 \mathrm{~cm}^{-1}$. Low frequency Raman spectroscopy could therefore be used for a clearer distinction of these two species in a clinker material.
\end{abstract}

Keywords: Portland cement clinker; Raman mapping; alite; belite; phonon density of states; CRYSTAL09

\section{Introduction}

Portland cement was invented at the beginning of 19th century, partly using previous knowledge from ancient Greece and Rome [1,2]. It is a powder material that, when in contact with water, transforms into a hardened cement paste by chemical reactions and physical processes. Portland cement is produced by milling Portland cement clinker with a few percentages of gypsum. The estimated world production of Portland cement in 2018 was 3.99 billion tones, of which China produced 54.5\% [3]. Currently, there exist numerous efforts toward reducing the amount of $\mathrm{CO}_{2}$ emitted into the atmosphere during cement clinker production. In 2018, it amounted to $1.5 \pm 0.12 \mathrm{GtCO}_{2}$ [4].

The main components of Portland cement clinker are expressed as weight percentages of lime $(\mathrm{CaO})$, silica $\left(\mathrm{SiO}_{2}\right)$, alumina $\left(\mathrm{Al}_{2} \mathrm{O}_{3}\right)$, and iron oxide $\left(\mathrm{Fe}_{2} \mathrm{O}_{3}\right)$, but the actual components occur as the following compounds: alite (tricalcium silicate $3 \mathrm{CaO} \cdot \mathrm{SiO}_{2}, \mathrm{C}_{3} \mathrm{~S}$ ), belite (dicalcium silicate $\left.2 \mathrm{CaO} \cdot \mathrm{SiO}_{2}, \mathrm{C} 2 \mathrm{~S}\right)$, tricalcium aluminate $\left(3 \mathrm{CaO} \cdot \mathrm{Al}_{2} \mathrm{O}_{3}, \mathrm{C}_{3} \mathrm{~A}\right.$ ), and tetracalcium aluminoferrite $\left(4 \mathrm{CaO} \cdot \mathrm{Al}_{2} \mathrm{O}_{3} \cdot \mathrm{Fe}_{2} \mathrm{O}_{3}, \mathrm{C}_{4} \mathrm{AF}\right)$. Although the relative amount of C3S, C2S, C3A, and C4AF can be estimated using the Bogue calculation [5], X-ray powder diffraction is the only exact physical method suitable for quantitative determination of phase composition [6]. According to Taylor [6], the following seven different polymorphs of alite have been confirmed in different temperature intervals: three triclinic phases, T1, T2, and T3; three monoclinic phases, M1, M2, and M3; and a rhombohedral phase, R, existing above $1070{ }^{\circ} \mathrm{C}$. In clinkers produced in an industrial kiln, alite is mainly present in the form of $\mathrm{M}_{1}$ or $\mathrm{M}_{3}$ polymorph with 3 to $4 \%$ of substituent oxides such as $\mathrm{MgO}$, alkaline sulfates 
or free lime. The content of $\mathrm{MgO}$ and sulfate $\left(\mathrm{SO}_{3}\right)$ determines whether the $\mathrm{R}$ polymorph transforms into an $\mathrm{M} 3$ or M1 polymorph on cooling from $1450{ }^{\circ} \mathrm{C}[7,8]$. Belite, $\mathrm{Ca}_{2} \mathrm{SiO}_{4}$, has the following five different polymorphs: $\alpha, \alpha_{\mathrm{H}}{ }^{\prime}, \alpha_{\mathrm{L}}{ }^{\prime}, \beta$, and $\gamma$ [9]. Industrial Portland cement contains belite that is almost entirely present in the form of monoclinic $\beta-\mathrm{C} 2 \mathrm{~S}$, with 4-6\% of substituting oxides, mainly $\mathrm{Al}_{2} \mathrm{O}_{3}$ and $\mathrm{Fe}_{2} \mathrm{O}_{3}$ [6].

The $\mathrm{CO}_{2}$ footprint of clinker phases decreases in the following order: $\mathrm{C} 3 \mathrm{~S}>\mathrm{C} 3 \mathrm{~A}>\mathrm{C} 2 \mathrm{~S}$ $>\mathrm{C} 4 \mathrm{AF}$ [10]. Lowering the $\mathrm{CO}_{2}$ footprint is achieved either by including supplementary cementitious materials into the Portland cement clinker, or by using chemical systems based on sulfoaluminate, sulfoferrite, and fluoroaluminate [1]. Tetracalcium trialuminate sulfate (C4A3S), also known as ye'elimite or Klein's salt, is the main phase in calcium sulfoaluminate cement, accompanied by belite (belite calcium sulfoaluminate clinker) or alite (alite calcium sulfoaluminate). Only one third of the $\mathrm{CO}_{2}$ released by the production of C3S is released during production of ye'elimite [11].

This work is planned as a first step for undertaking Raman/AFM mapping analysis of the calcium-silicate-hydrate (C-S-H) that develops upon cement hydration [12,13]. Several Raman mapping analyses on a hydrated clinker have been performed [14-17], which have proven that Raman spectroscopy is a technique by which water and hydrates can be successfully monitored. Additionally, atomic force microscopy was used for pore size determination [13]. As stated by Stutzmann et al. [18], in order to obtain high contrast scanning electron microscopy images of the clinker, samples need to be embedded in epoxy resin, cut, and polished, first by using silicon carbide paper of increasing degrees of grit and then, using a diamond paste with finer and finer dimensions of particles. Superposition of the image obtained by backscattered electrons and the images obtained using an energy dispersive X-ray analyser for each selected element (e.g., S, K, Al, Mg, Fe, Na...), using appropriate software, allows one to obtain a segmentation image showing regions of spatial distribution of chosen elements. This contemporary golden standard procedure is a sequel to the light microscopy of the Portland cement clinker of Henry de Chatelier (1887), which is still very useful in distinguishing alite and belite microcrystals [19]. Two major modes of operation for obtaining images using atomic force microscopy, tapping, and contact mode, have both been used in the study of clinker material [20,21]. Here, we opted for the examination of an untreated clinker grain using atomic force microscopy.

Proper assignment of the vibrational bands observed for dry clinker material is a prerequisite for confident analysis of Raman cement's hydration spectra. In spite of an abundance of spectroscopic studies on single crystal $\mathrm{Ca}(\mathrm{OH})_{2}$, for example (Dawson et al. [22], Buchanan et al. [23], Oehler and Günthard [24], and online database spectra [25]), one can find band assignments of $\mathrm{Ca}(\mathrm{OH})_{2}$ in the studies of Raman mapping of cement paste that contradict them [17]. A theoretical calculation of the vibrational density of states of crystalline oxide phases helps to discern fundamental phonon bands from overtone and combination bands, as well as from spectral features of other chemical species, e.g., $\mathrm{CaO}$ crystallizes in the $\mathrm{F} m \overline{3} m$ space group and disposes with a single triply degenerate phonon of $F_{u}$ symmetry, which is only observable in a far infrared absorption spectrum. Its second-order Raman spectrum was discussed in the work by Voisin and Mon [26] and Rieder et al. [27]. Quicklime exposed to atmosphere reacts immediately with water vapour and carbon dioxide, producing calcium hydroxide and different polymorphs of calcium carbonate, as documented, e.g., in the work of S. Martínez-Ramírez et al. [28], López-Arce et al. [29], Dubina et al. [30], Schmid and Dariz [31], and Kaszowska et al. [32]. Interpreting Raman spectra in the study of lime and clinker materials in general is not straightforward, because anomalous bands have been recorded to appear when lasers with a 1064-nanometer wavelength in the near infrared region was used [33]. Reproducible vibrational Raman spectra were obtained with green $(514.5 \mathrm{~nm}, 532 \mathrm{~nm})$, blue $(488 \mathrm{~nm})$, or red $(632 \mathrm{~nm})$ excitation laser lines, as demonstrated in articles by Bensted [34,35], Krishnamurthy and Soots (gypsum) [36], Conjeaud and Boyer [37], Handke [38], Ibááñez et al. [39], and Garg and Wang [40]. Often referred to as fluorescence bands or anomalous bands, strong maxima at $574 \mathrm{~cm}^{-1}$ for C3S or at $1023 \mathrm{~cm}^{-1}$ for C2S were observed by Dyer et al. [41], and similar 
bands found by Bonen et al. [42], Aminzadeh et al. [43], and Newman et al. [44], all on top of the very broad intense background. In their study of archaeological burial sites, the Raman spectra of lime substances were analysed with 785 and $1064 \mathrm{~nm}$ excitation by Schotsmans et al. and it was concluded that the origin of anomalous bands comes from electronic transitions [45]. In a paper by Potgieter-Vermaak et al. [46], one can find Raman bands of alite and belite tabulated with respect to the laser excitation source, while Skibsted and Hall discuss more Raman results [47]. A summary of Raman bands assignments can be found in a review article by Black [48].

The carbonation of calcium hydroxide nanoparticles exposed to external humidity was studied by López-Arce et al. [29], using both transmission electron microscopy, energy dispersive X-ray spectroscopy, environmental scanning electron microscopy combined with $\mathrm{X}$-ray diffraction, and Raman spectroscopy. We briefly state their results in the following. X-ray diffractograms characteristic of portlandite are present after 7 days of hydration at relative humidity of $33 \%$, while calcite and calcite monohydrate are identified together with a very broad maximum between $2 \theta=16^{\circ}$ and $28^{\circ}$ much later after 28 days. The corresponding Raman spectra display only a portlandite band at $356 \mathrm{~cm}^{-1}$ and a calcite band at $1083 \mathrm{~cm}^{-1}$. Portlandite reacts with $\mathrm{CO}_{2}$ (relative humidity of $54 \%$ ) and after 7 days forms mainly vaterite, identified by two bands in the interval between 1070 and $1090 \mathrm{~cm}^{-1}$. On increasing the humidity further to $75 \%$, X-ray diffraction experiments gave evidence of an amorphous phase, together with aragonite, monohydrocalcite, and vaterite [29]. The corresponding Raman spectra display an intense band at $1086 \mathrm{~cm}^{-1}$, with weak bands at 280 and $710 \mathrm{~cm}^{-1}$; the band at $710 \mathrm{~cm}^{-1}$ was characteristic of aragonite. A detailed deconvolution of the Raman bands of carbonates formed at different depths in lime mortar was performed by Martínez-Ramírez et al. [28]. Although surface Raman spectra only permitted assignments of the bands that are characteristic of calcite, analysis at different depths revealed the presence of aragonite. No vaterite was detected in their samples.

In this work, we shall present the results on dry clinker material coming from three different sources - the first was granular, consisting mainly of alite in the $\mathrm{M}_{3}$ phase; the second was a Portland cement powder of the CEM I type; and the third, a polished calcium sulfoaluminate clinker. All of the clinker materials were examined using Raman imaging spectroscopy, while both atomic force microscopy and Raman imaging experiments were performed for clinker 217. To facilitate the assignment of portlandite, alite, and belite vibrational bands in the clinker spectra, the density functional theory was employed in the calculation of the vibrational density of states (VDOS) for $\mathrm{Ca}(\mathrm{OH})_{2}$, monoclinic belite ( $\beta$ phase) [49], and the averaged structure of alite polymorph belonging to the $\left\langle\mathrm{M}>P_{c}\right.$ group [50-52], by means of a CRYSTAL09 program [53]. The calculation of alite's and belite's VDOS is, as far authors are aware, published for the first time.

\section{Experimental}

A specification of the composition of clinker 217 and sulfoaluminate cement is given in Table 1. In clinker 217, the $\mathrm{CaO}$ to $\mathrm{SiO}_{2}$ mass ratio was 3.24, and in calcium sulfoaluminate (CSA) cement it was 4.39. The mass percentage of $\mathrm{MgO}$ in clinker 217 was $2.17 \%$, while it was $4.66 \%$ in CSA cement. Overall contribution of $3 \mathrm{CaO} \cdot \mathrm{SiO}_{2}+2 \mathrm{CaO} \cdot \mathrm{SiO}_{2}$ in mass $\%$ was greater than $66.7 \%$ in clinker 217 , which means that it satisfied the norm HRN EN 197-1:2012 as Portland cement clinker. 
Table 1. Chemical composition of clinker 217. Analysis performed using Institute IGH d.o.o. Zagreb.

\begin{tabular}{|c|c|c|}
\hline Properties & $\begin{array}{c}\text { Clinker } 217 \\
\% \text { Mass }\end{array}$ & $\begin{array}{c}\text { Calcium Sulfoaluminate } \\
\text { Cement } \\
\% \text { Mass }\end{array}$ \\
\hline Loss on ignition & 0.25 & 0.92 \\
\hline Sulfate content, $\mathrm{SO}_{3}$ & $1 . \overline{7}$ & $-\cdots---\overline{11.49}$ \\
\hline Insoluble residue in $\mathrm{HCl} i \mathrm{Na} \mathrm{CO}_{3}$ & $0 . \overline{50}$ & 2.54 \\
\hline Insoluble residue in $\mathrm{HCl} i \mathrm{KOH}$ & 0.55 & 1.96 \\
\hline Sulfide content, $S^{2-}$ & 0.02 & 0.00 \\
\hline Manganese oxide content, $\mathrm{MnO}$ & $\overline{0 .}-\overline{1}$ & $\begin{array}{r}--\overline{-}-\overline{1} \\
0.157\end{array}$ \\
\hline Total silica content $\mathrm{SiO}_{2}$ & 20.24 & 9.12 \\
\hline Iron (III) oxide content, $\mathrm{Fe}_{2} \mathrm{O}_{3}$ & 2.89 & $-----\overline{1}-\overline{1}$ \\
\hline Aluminium oxide content, $\mathrm{Al}_{2} \mathrm{O}_{3}$ & $4 . \overline{5} 6$ & 32.82 \\
\hline Calcium oxide content, $\mathrm{CaO}$ (13.14) & 65.50 & 40.08 \\
\hline Magnesium oxide content $\mathrm{MgO}$ & 2.17 & 4.66 \\
\hline Chloride content, $\mathrm{Cl}^{-}$ & $-\overline{0.014}-$ & $\begin{array}{c}----\overline{188} \\
0 .----\cdot]\end{array}$ \\
\hline Sodium oxide content, $\mathrm{Na}_{2} \mathrm{O}$ & $0 . \overline{2} 6$ & 0.48 \\
\hline Potassium oxide content, $\mathrm{K}_{2} \mathrm{O}$ & 1.07 & 0.71 \\
\hline Sodium oxide equivalent, $\mathrm{Na}_{2} \mathrm{O}$ & 0.96 & 1.03 \\
\hline Carbon dioxide content, $\mathrm{CO}_{2}$ & 0.00 & 0.22 \\
\hline
\end{tabular}

X-ray powder diffraction data of clinker 217 were collected in the 2nd eta range 10-70 at room temperature on a Bruker D8 Discover diffractometer (Zagreb, Croatia) equipped with an LYNXEYE XE-T detector (Zagreb, Croatia), in theta-theta geometry. The results are shown in Figure 1. Cement powder of the CEM I type was also included in this study. It consisted of the clinker 217 with a few percent of gypsum added.

\subsection{Computational Details}

For ab initio calculation of phonons of the $\mathrm{Ca}_{2} \mathrm{SiO}_{4}$ and $\mathrm{Ca}_{3} \mathrm{SiO}_{5}$, A CRYSTAL09 program was used [53], running on an HP Z640 workstation (Ruđer Bošković Institute, Zagreb, Croatia) using 8 processors. Atomic positions were optimised, starting from crystal geometry (C2S [49], C3S [50]) obtained using $X$ ray powder diffraction, which provided sufficient precision for the calculation to converge and later gave all positive vibrations. The three lowest modes were acoustic modes with zero frequencies. For calcium and oxygen atoms, basis sets were taken from Valenzano's work on calcite [54], while, for silicon, the basis set refined on $\mathrm{Mg}_{3} \mathrm{Al}_{2} \mathrm{Si}_{3} \mathrm{O}_{12}$ [55] and $\mathrm{Mg}_{2} \mathrm{SiO}_{4}$ [56] was used. Density functional theory was implemented using the correlation functional of Vosko, Wilk, and Nusair [57], and a local density approximation for the exchange part of the Hamiltonian [58]. The $35 \%$ of mixing of old wavefunction with the new one was applied in each cycle. The convergence criterion for energy was $10^{-9} \mathrm{Ha}$. The theoretical phonon density of states for $\mathrm{C} 2 \mathrm{~S}$ and $\mathrm{C} 3 \mathrm{~S}$ are presented in Figure 2. The outputs are available as Supplementary information.

\subsection{Raman Spectroscopy of Clinker}

Altogether, the Raman spectra were collected using the following three different instruments: HORIBA Jobin-Yvon T64000 triple monochromator located at the Ruđer Bošković Institute, Zagreb, Croatia; Labram HR Evolution located at the HORIBA JobinYvon SAS Application laboratory at Lille, France; and the third instrument was WITec alpha 300 RA located at WITec factory in Ulm, Germany. 
The Raman spectra of clinker 217, cement powder of CEM I type, and of polished sulfoaluminate clinker were performed with a T64000 HORIBA Jobin-Yvon Raman spectrometer, Zagreb, Croatia, equipped with three gratings, having 1800 grooves per mm, $532 \mathrm{~nm}$ laser excitation, and a 50× long working distance objective. The time constant was between 5 and $20 \mathrm{~s}$, and the number of accumulations varied up to 16 . The laser power of $532 \mathrm{~nm}$ DPSS laser (ChangChun Industries Ltd., Changchun China) at the sample was $20 \mathrm{~mW}$. Characteristic spectra are presented in Figures 3 and 4, and in Supplementary Figures S1-S3.

Colocalised Raman and atomic force microscopy mapping of granular clinker 217, which was performed with a Labram HR Evolution, used the $100 \times$ Mitutoyo objective on a 30-micrometer by 30-micrometer mapped area, used a scanning step of $0.5 \mu \mathrm{m}$, and $0.5 \mathrm{~s}$ time per acquisition point. The $532 \mathrm{~nm}$ laser with an operating power of $6 \mathrm{~mW}$ served as an excitation. The final Raman chemical image map (shown in Figure 5a) was formed using CLS fitting, a proprietary HORIBA software (Lille, France) procedure, which starts from a set of manually selected reference sets, shown on the right of Figure 5a, and finds a linear combination of reference spectra that best fits the observed data. Atomic force microscopy measurements were performed on the central part, $5 \mu \mathrm{m}$ by $5 \mu \mathrm{m}$ of the area was selected for Raman measurements (see Figure 5b) using AIST-NT Smart SPM (Novato, CA, USA) in the Normal force mode, using gold etched tip glued on a tuning fork.

Raman spectral imaging on clinker 217 was performed at WITec company (Ulm, Germany) using WITec alpha 300 RA spectrometer on a scanned area of $60 \mu \mathrm{m}$ by $60 \mu \mathrm{m}$, using 120 points per line and 120 lines per image with an integration time of 0.2 seconds. The optically pumped semiconductor laser was used for $532 \mathrm{~nm}$ excitation. Spectrometer UHTS 300 (Ulm, Germany) had a grating with 600 grooves per mm, and the CCD DU970_UVB detector (Oxford, UK). Spectra were analysed using WITec ProjectFOUR plus software software (Ulm, Germany) and, as a result, five characteristic spectra were selected. The sample area was colour coded and the obtained map is presented in Figure 6.

\section{Results and Discussion}

In order to correctly attribute the observed bands in the clinker, a calculation of phonons for $\mathrm{Ca}(\mathrm{OH})_{2}$ using LDA for exchange and VWN correlation pseudopotentials as implemented in the CRYSTAL09 program [53] was performed. The results are given in Table 2. Portlandite crystallizes in space group $P \overline{3} m 1$ with a single formula unit per unit cell $\left(a=3.593 \AA, \mathrm{b}=3.593 \AA, \mathrm{c}=4.909 \AA, \alpha=90^{\circ}, \beta=90^{\circ}, \gamma=120^{\circ},[59]\right)$.

Table 2. Comparison of calculated with observed phonons in $\mathrm{Ca}(\mathrm{OH})_{2}\left(\mathrm{~cm}^{-1}\right)$.

\begin{tabular}{ccc}
\hline Phonon Symmetry & $\begin{array}{c}\text { Calculated, This Work } \\
\text { (CRYSTAL09) }\end{array}$ & $\begin{array}{c}\text { Observed } \\
\text { (Dawson et al. [22]) }\end{array}$ \\
\hline$A_{2 u}$ & 3662 & 3640 \\
$A_{1 g}$ & 3626 & 3620 \\
$E_{g}$ & 721 & 680 \\
$E_{u}$ & 377 & 373 \\
$A_{1 g}$ & 374 & 357 \\
$A_{2 u}$ & 369 & 334 \\
$E_{u}$ & 309 & 287 \\
$E_{g}$ & 265 & 252 \\
\hline
\end{tabular}

One of the first applications of density functional theory to portlandite was that of Baranek et al. using the CRYSTAL98 code [60]. The net atomic charges obtained by Mulliken's partition were (using LDA + VWN and B3LYP functionals [61-66]) +1.722e (Ca), $-1.202 e(\mathrm{O})$, and $+0.341 e(\mathrm{H})$. In comparison, Manzano et al. [67] used the periodic DFT code SIESTA with Perdew, Burke, and Ernzerhof's exchange correlation functional [68] to obtain the averaged ionic charges of $+1.41 e(\mathrm{Ca}),-0.85 e(\mathrm{O})$, and $+0.16 e(\mathrm{H})$ for $\mathrm{Ca}(\mathrm{OH})_{2}$. Portlandite is a layered structure, the binding energy between two layers was calculated 
as $-0.015 \mathrm{Ha}$ [60]. The nature of the chemical bonds that Baranek et al. elucidated from Mulliken's population data is as follows: the $\mathrm{Ca}-\mathrm{O}$ bond has a very small electron population value $(-0.036)$, hence it is ionic; while the $\mathrm{O}-\mathrm{H}$ bond has a population value of 0.478 and is therefore mainly covalent. Additionally, the $\mathrm{O}-\mathrm{H}$ stretching vibration that is observed in the infrared spectrum at $3644 \mathrm{~cm}^{-1}$ and at $3620 \mathrm{~cm}^{-1}$ in the Raman spectrum [22] proves the covalent character of the $\mathrm{O}-\mathrm{H}$ bond in $\mathrm{Ca}(\mathrm{OH})_{2}$. Manzano et al. studied the hydration of the calcium oxide surface and concluded that the $\mathrm{CaO}$ surface will keep its structure for water amounts up to 6.43 molecules $/ \mathrm{nm}^{2}$ and will distort at water amounts of about 8.58 molecules $/ \mathrm{nm}^{2}$, thus providing the interval of water coverage important for the catalytic behaviour of $\mathrm{CaO}$ [67].

The strongest Raman bands of $\mathrm{Ca}(\mathrm{OH})_{2}$ are the band at 3620 and at $357 \mathrm{~cm}^{-1}$, both belonging to $A_{1 g}$ symmetry. The broad band at $680 \mathrm{~cm}^{-1}$, observed in the Raman spectrum of an oriented single crystal study by Dawson to $E_{g}$ phonon [22], was assigned to adsorbed water by Dubina et al. [30]. Dubina et al. reported X-ray diffraction patterns of lime at 10, $20,40,60$, and $80 \%$ of relative humidity, showing the peaks corresponding to portlandite and to carbonation products appearing at a relative humidity of $40 \%$ and higher [30]. A band at $1083 \mathrm{~cm}^{-1}$ in the Raman spectra of lime at $10 \%$ relative humidity was assigned to amorphous $\mathrm{CaCO}_{3}$, while it was not possible to detect this amorphous material in X-ray diffractograms. At $40 \%$ relative humidity, the diffractograms of lime contained peaks corresponding to aragonite $\left(701,706 \mathrm{~cm}^{-1}\right)$, vaterite $\left(1075 \mathrm{~cm}^{-1}\right)$, and calcite $\mathrm{CaCO}_{3}$ $\left(1085 \mathrm{~cm}^{-1}\right)$ [30].

In Figure 1, a comparison of the calculated X-ray diffraction alite powder patterns for the $\mathrm{M}_{1} P c$ structure determined by de Noirfontaine et al. [50-52], and the $C m$ structure determined by Nishi, Takeuchi and, Maki [69] for $\mathrm{M}_{3}$ phase with experimental powder $\mathrm{X}$-ray diffraction pattern of clinker 217 is given. There is an overall agreement of clinker 217 maxima with those of Nishi et al., and we conclude that the alite present in clinker 217 is dominantly monoclinic $\mathrm{M}_{3}$, of space group $\mathrm{Cm}$. In order to be able to interpret the Raman spectra of clinker samples, we calculated the phonon density of states for the monoclinic C3S Pc structure, as determined by de Noirfontaine et al. [50-52]. The parameters of the C3S structure are compared with those of $\beta-\mathrm{C} 2 \mathrm{~S}$ in Table 3. Atoms have partial occupancy in the structure determined by Nishi, and that option is not implemented in the CRYSTAL0 9 program that we had at our disposal. Therefore, we chose the $\mathrm{M}_{1} P c$ structure for the calculation of phonons. The $P_{c}$ structure of Noirfontaine et al. has only a glide plane placed at $0, b / 2$, and at $b$. For this structure, we succeeded in obtaining all the positive frequencies for the 162 modes that are observable both in the Raman and in the infrared spectrum. Both the C3S and C2S structures were successfully optimised using OPTGEOM command. Various functions (PBE, LDA + VWN, PBESOL, etc.) gave slightly different total energies. The final result for the C3S structure with 54 atoms in a unit cell was $-16140.66 \mathrm{Ha}$, and for the $P 2_{1} / n \mathrm{C} 2 \mathrm{~S}$ structure, $-7757.78 \mathrm{Ha}$, when VWN/LDA correlation/exchange functions were used.

Table 3. Comparison of two monoclinic crystal structures of $\mathrm{Ca}_{3} \mathrm{SiO}_{5}$ with the structure of $\beta-\mathrm{C} 2 \mathrm{~S}$.

\begin{tabular}{cccc}
\hline Compound & C3S & C3S & C2S \\
\hline space symmetry & $P c$ & $C m$ & $P 2_{1} / n$ \\
structure type & $\mathrm{M} 1$ & $\mathrm{M} 3$ & $\beta$ \\
$a$ & $9.2912 \AA$ & $33.083 \AA$ & $5.5075 \AA$ \\
$b$ & $7.059 \AA$ & $7.027 \AA$ & $6.7509 \AA$ \\
$c$ & $12.2575 \AA$ & $18.499 \AA$ & $9.3055 \AA$ \\
$\beta$ & $116.03^{\circ}$ & $94.12^{\circ}$ & $94.597^{\circ}$ \\
references & de Noirfontaine & Nishi et al. [69] & Jost $[49]$ \\
\hline
\end{tabular}




\section{- $\mathrm{M}_{1}$ Pc C3S de Noirfontaine \\ - clinker 217 \\ - $\mathrm{M}_{3} \mathrm{Cm}$ C3S Nishi, Takeuchi, Maki}

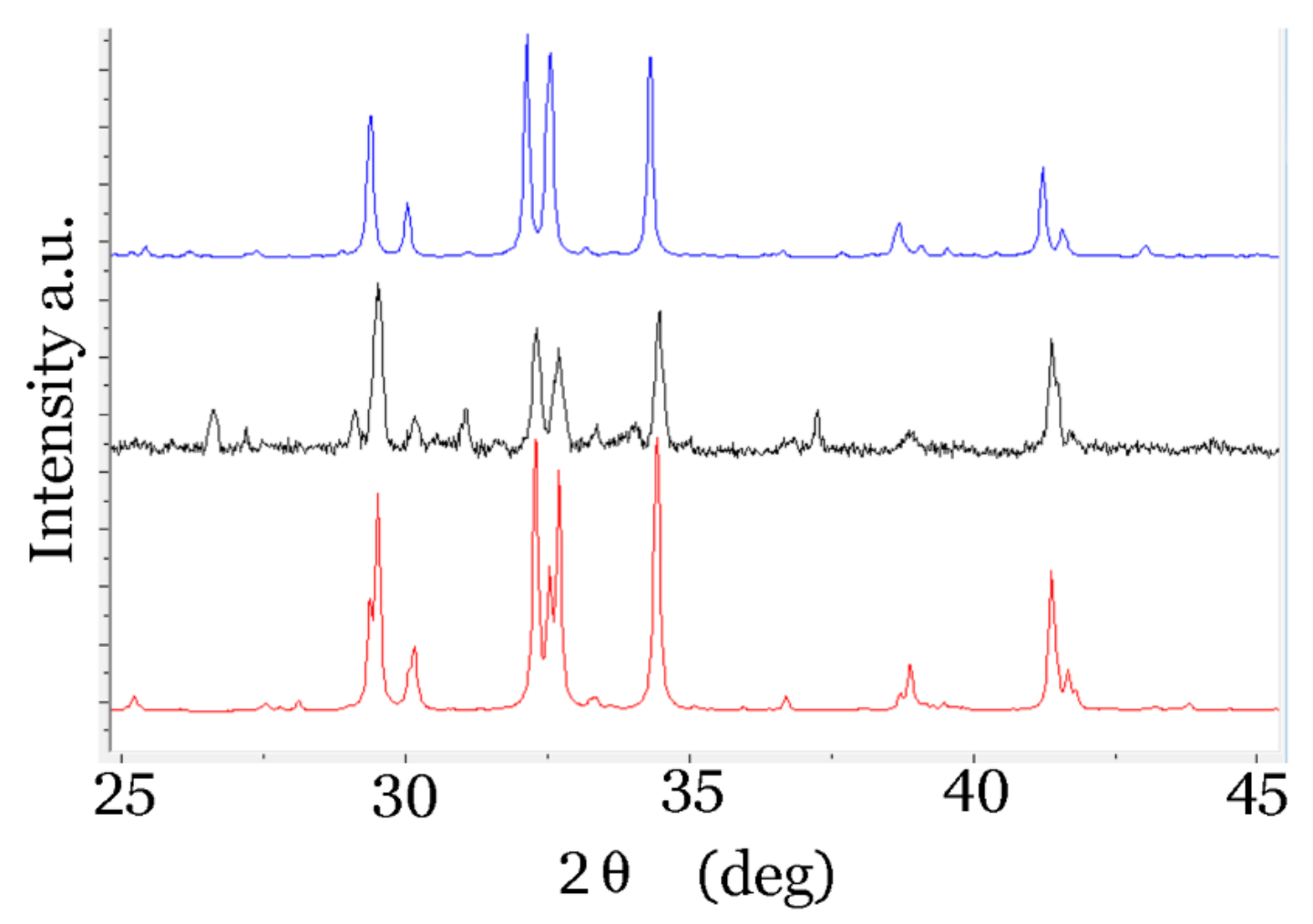

Figure 1. Comparison of the diffractogram of clinker 217 (middle) with the diffractogram of the phase $\mathrm{M}_{1} P_{c}$ [50] (above) and with the $\mathrm{M}_{3} \mathrm{Cm}$ [69] (below) (interval $25^{\circ}-45^{\circ}$ ).

The results are compared with the Raman spectrum of belite calculated for the $P 2_{1} / n$ crystal structure of the $\beta$ polymorph [49], where in total $21 \mathrm{Ag}_{\mathrm{g}}$ and $21 \mathrm{Bg}_{\mathrm{g}}$ modes are expected, in Figure 2. As one can see, both for C3S and C2S, there is a gap in the calculated phonon densities, from 560 to $810 \mathrm{~cm}^{-1}$, present both for M1 (de Noirfontaine $P c$ ) and for the $\beta$ polymorph of $\mathrm{C} 2 \mathrm{~S}$. This spectral window offers the possibility for a confident assignment of bands originating from other chemical species such as calcium aluminates. Contrary to $\mathrm{Ca}_{3} \mathrm{SiO}_{5}, \beta-\mathrm{Ca}_{2} \mathrm{SiO}_{4}$ has no bands below $100 \mathrm{~cm}^{-1}$, as predicted by this calculation. This fact could be exploited in the assignment of Raman bands of cement powder and the clinker if one were to record spectra without the interference of the rotational spectrum of air. This is, however, highly unlikely unless a vacuum chamber is used, given the long acquisition times necessary to obtain a good signal to noise ratio (see Figure 3, where a low frequency region of the Raman spectrum of cement powder is included, and it contains rotational bands of air below $100 \mathrm{~cm}^{-1}$ ).

One can correlate atomic motions in $\mathrm{C} 3 \mathrm{~S}$ and $\mathrm{C} 2 \mathrm{~S}$ with the corresponding phonon frequencies given in the outputs of CRYSTAL09 program available in the Supplementary Material by uploading the outputs to the website of the CRYSPLOT program [70]. In this way, one can assign the bands between 800 and $1000 \mathrm{~cm}^{-1}$ to Si-O stretching motions, while translational motions of calcium, oxygen, and silicon tetrahedra have their corresponding bands below $560 \mathrm{~cm}^{-1}$. In Table 4, the position of the observed Raman bands of the CEM I powder, clinker 217, and the sulfoaluminate clinker are compared and assigned [48]. The representative spectra are displayed in Figures 3 and 4 and in Supplementary Figures S1-S3. 

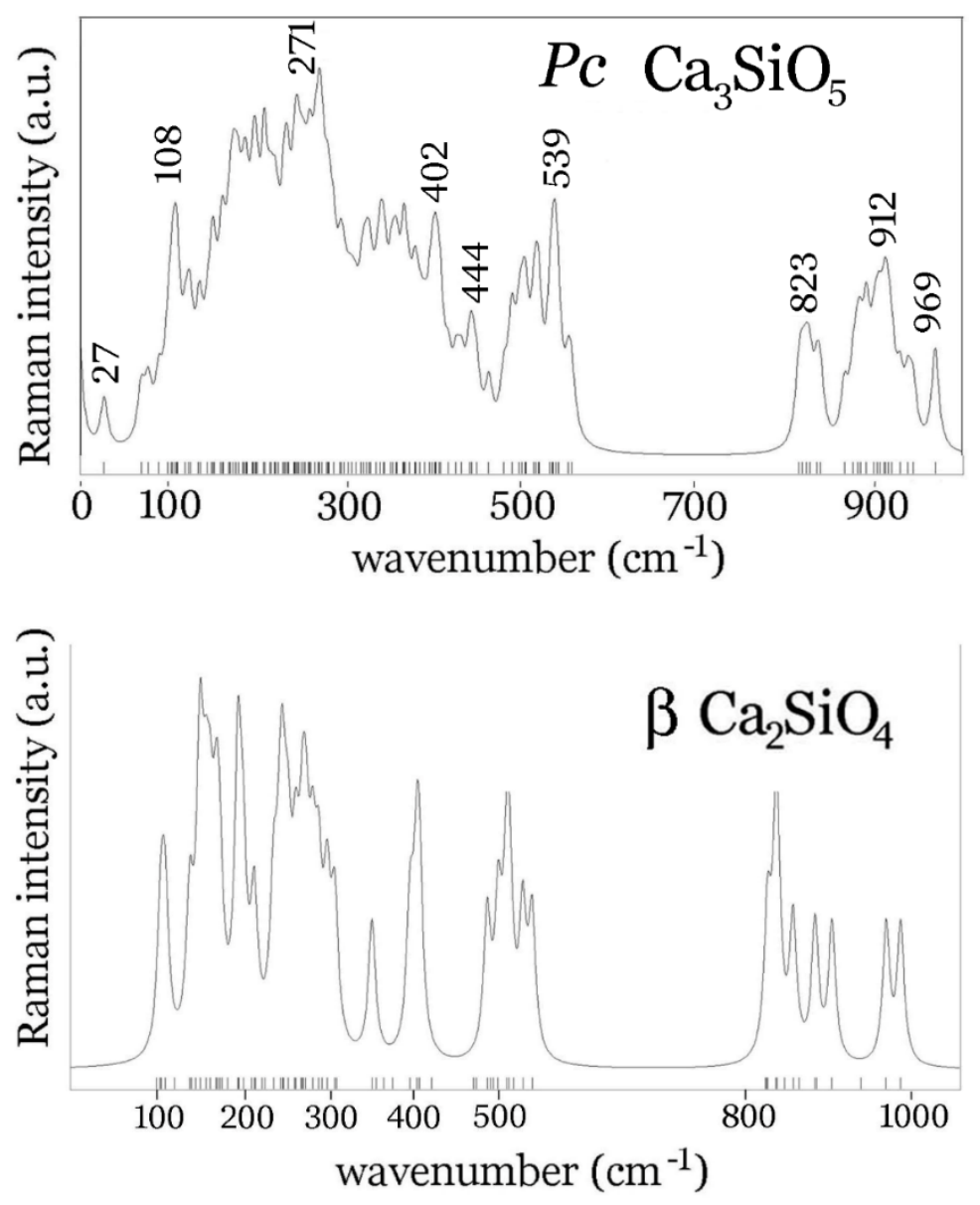

Figure 2. Calculated phonon density of states for $\mathrm{Ca}_{3} \mathrm{SiO}_{5}$ and $\mathrm{Ca}_{2} \mathrm{SiO}_{4}$ crystals.

Table 4. Observed Raman bands of cement CEM I powder, clinker 217 grains, and polished calcium sulfoaluminate clinker embedded in resin together with the assignment of bands $\left(\mathrm{cm}^{-1}\right)$. Abbreviations: $\mathrm{C} 3 \mathrm{~S}-\mathrm{Ca}_{3} \mathrm{SiO}_{5}, \mathrm{C}_{2} \mathrm{~S}-\mathrm{Ca}_{2} \mathrm{SiO}_{4}$, $\mathrm{C} 3 \mathrm{~A}-3 \mathrm{CaO} \cdot \mathrm{Al}_{2} \mathrm{O}_{3}, \mathrm{C} 4 \mathrm{AF}-\mathrm{CaO} \cdot \mathrm{Al}_{2} \mathrm{O}_{3} \cdot \mathrm{Fe}_{2} \mathrm{O}_{3}$.

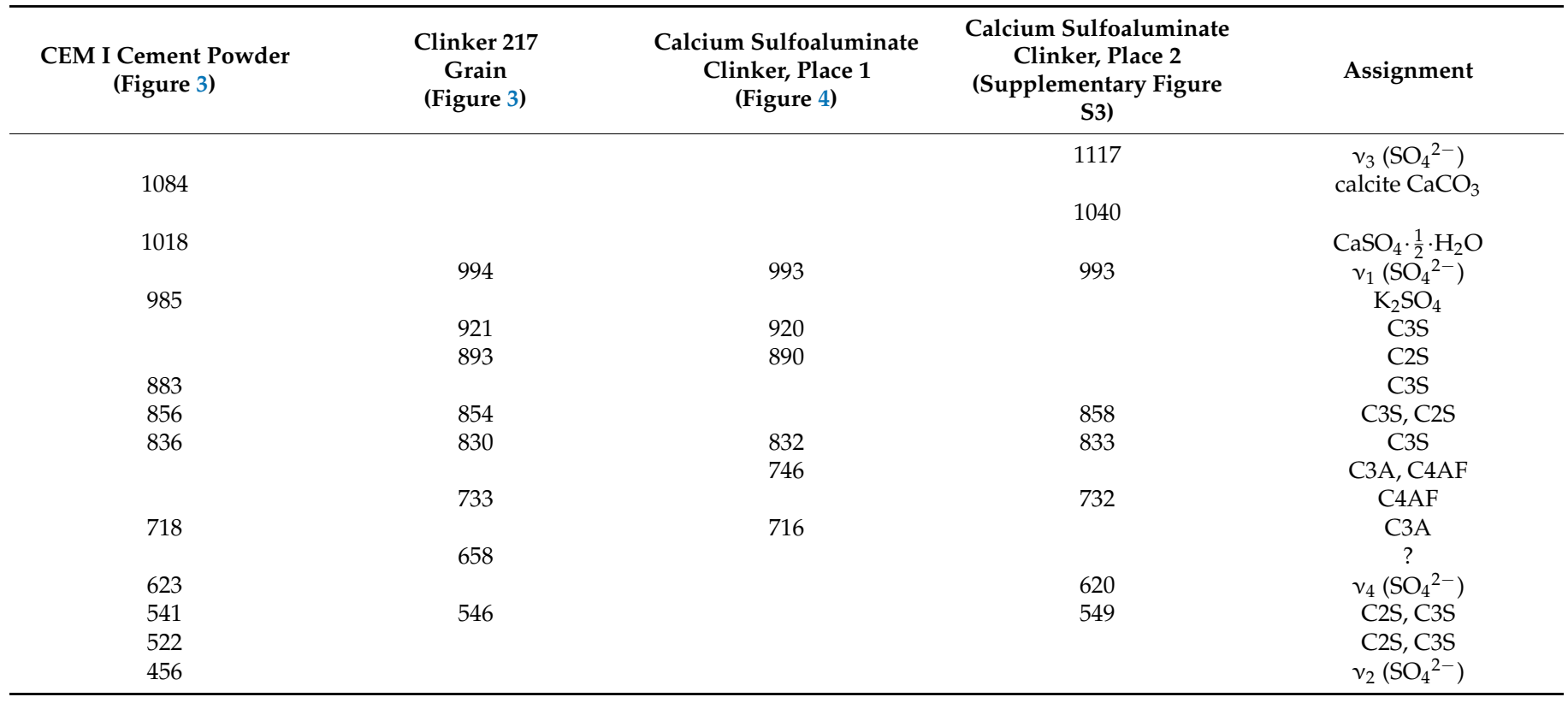


In the Raman spectrum of CEM I, the sharp bands observed at 985, 623, and 456 $\mathrm{cm}^{-1}$ (Figure 3) that correspond to vibrations of $\mathrm{SO}_{4}{ }^{2-}$ tetrahedra, are also present in the spectrum of gypsum, $\mathrm{CaSO}_{4} \cdot 2 \mathrm{H}_{2} \mathrm{O}$ (see Supplementary Figure S1), but not in the Raman spectrum of clinker 217 (Figure 3). A sharp band at $993 \mathrm{~cm}^{-1}$ in the Raman spectrum of the calcium sulfoaluminate clinker is assigned to the symmetric stretching of $\mathrm{SO}_{4}{ }^{2-}$ coming from ye'elimite (Figure 4). The broad bands in the $600-800 \mathrm{~cm}^{-1}$ interval are assigned mainly to tricalcium aluminate $\mathrm{C} 3 \mathrm{~A}$ or tetracalcium aluminate ferrite, with the band at $658 \mathrm{~cm}^{-1}$ in the spectrum of clinker 217 left unassigned. Black reported the frequent observation of a band at $642 \mathrm{~cm}^{-1}$ in alite by several groups, without assignment [48].

One of the key advantages of Raman spectroscopy is its ability to provide information on the chemical composition of an untreated sample. As Figures 3 and 4, and Supplementary Figures S1-S3, show, the spectral information obtained may differ from point to point on the sample, since the clinker and cement powder are highly heterogeneous.

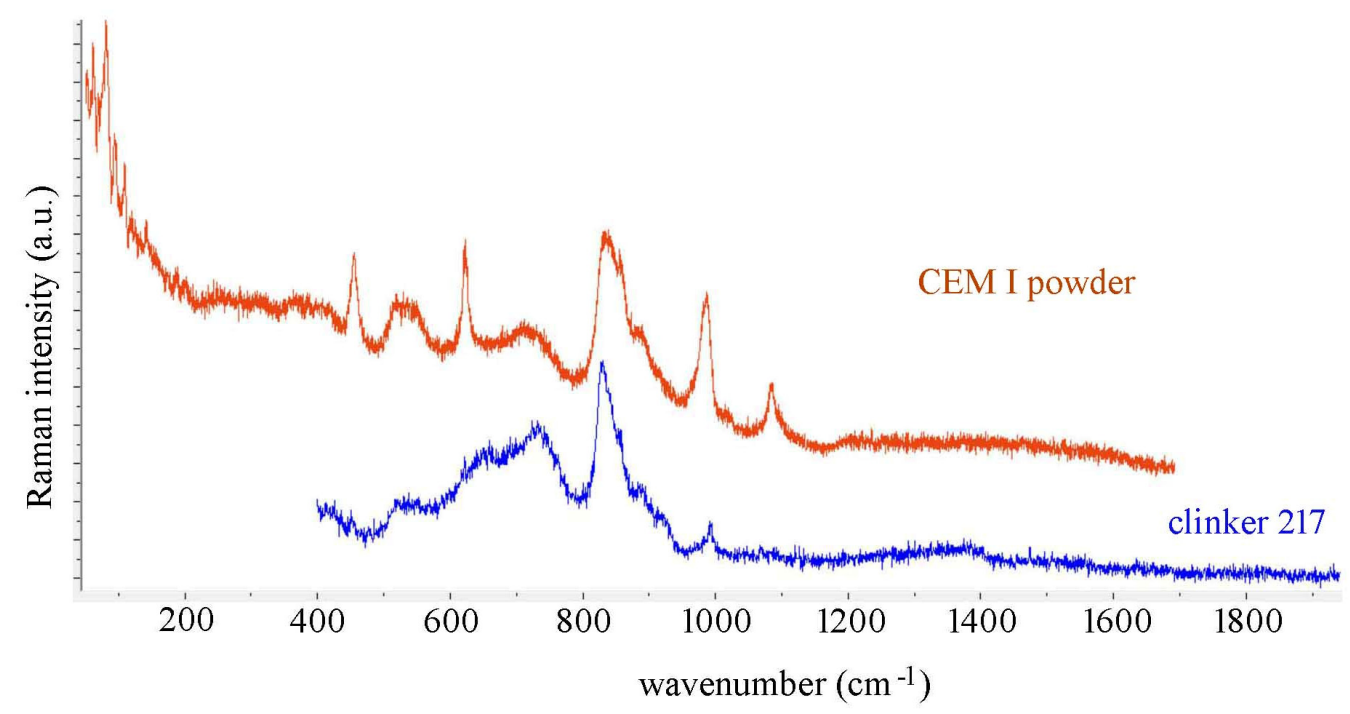

Figure 3. Comparison of Raman spectra of CEM I powder (clinker 217 with few percent of gypsum) and clinker 217.

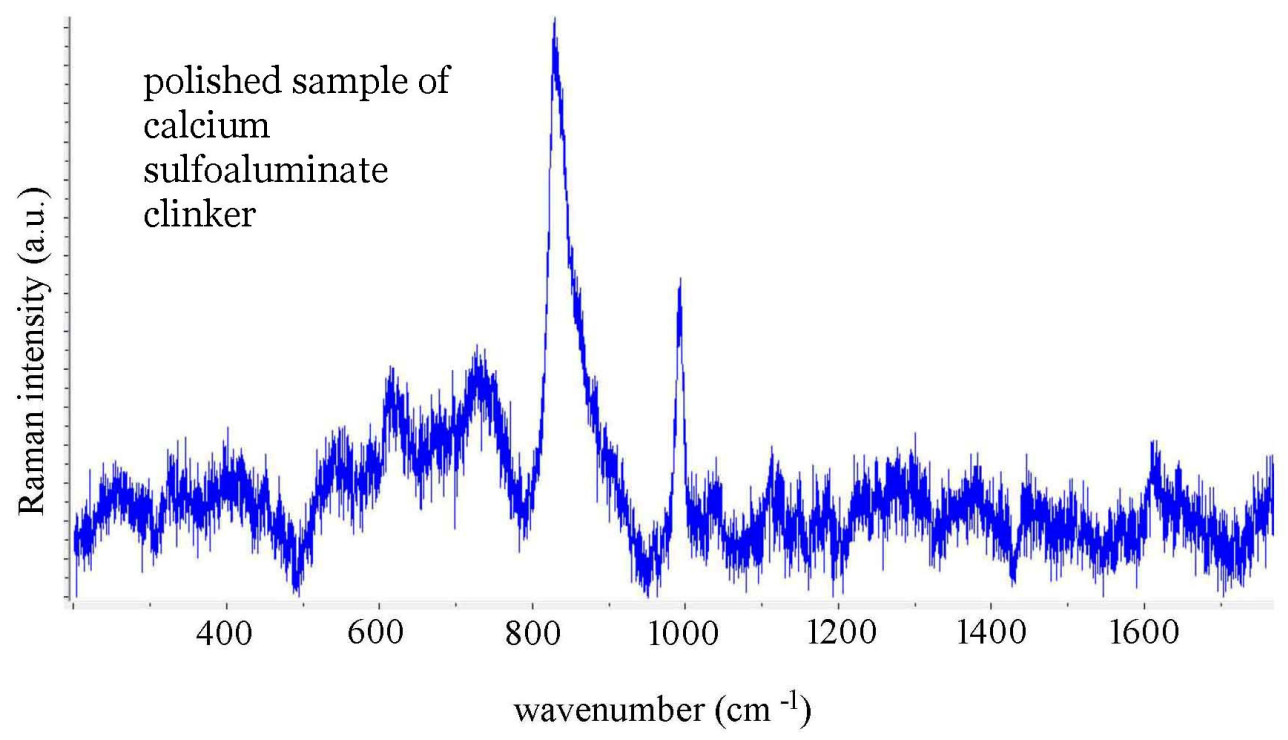

Figure 4. Raman spectrum of polished sample of calcium sulfoaluminate clinker.

One can acquire spectral information for the whole surface by using a Raman imaging procedure. Scanning the surface sequentially and storing spectra gives information on 
the spatial distribution of the chemical species present. One such Raman mapping was performed on a 30-micrometer by 30-micrometer area of a clinker 217 grain using a HORIBA Jobin-Yvon Labram instrument (Lille, France), and for each point a "CLS fitting procedure" was performed. This procedure found a linear combination of the reference component spectra displayed on the right of Figure $5 \mathrm{a}$, which best fits the raw data for every point on the map. The reference spectra were selected manually within the spectral array of the map. The spectrum denoted with 1 is mainly alite and belite $\left(818,869 \mathrm{~cm}^{-1}\right) ; \mathbf{2}$ has a strong band at $346 \mathrm{~cm}^{-1}$, corresponding to portlandite $\mathrm{Ca}(\mathrm{OH})_{2}$, and an amorphous $\mathrm{CaCO}_{3}$ band at $1073 \mathrm{~cm}^{-1} ; 3$ has a strong contribution from calcium aluminates and calcium aluminoferrites $\left(710 \mathrm{~cm}^{-1}\right)$; and 4 is mainly a fluorescent background. By colour coding each area with the same colour that corresponds to the predominating spectrum of that area, one obtains the image on the left of Figure $5 \mathrm{a}$.

Choosing a smaller area assigned to portlandite and performing an atomic force microscopy scan across a 5-micrometer by 5 -micrometer square, one observes the layered structure of $\mathrm{Ca}(\mathrm{OH})_{2}$ (Figure $5 \mathrm{~b}$ ).

When a smaller part of that area $(2 \mu \mathrm{m}$ by $2 \mu \mathrm{m}$ square), is scanned further, one observes spherulites characteristic of amorphous calcium carbonate [71]. Another Raman mapping experiment was performed using a WITec alpha $300 \mathrm{RA}$ instrument and the results are displayed in Figure 6, using a red colour for the distribution of alite and belite, while the blue colour corresponds to tricalcium aluminate and calcium aluminoferrite. Sulfates can be detected in the clinker as well, and the strongest symmetric stretching mode $v_{1}\left(\mathrm{SO}_{4}{ }^{2-}\right)$ is clearly visible in the spectral component 3 that is colour coded green (see Supplementary Figure $\mathrm{S} 1$ where the spectrum of gypsum, $\mathrm{CaSO}_{4} \cdot 2 \mathrm{H}_{2} \mathrm{O}$, is presented). The remaining two characteristic spectra are that of $\mathrm{Ca}(\mathrm{OH})_{2}$, with two prominent bands at 356 and $3620 \mathrm{~cm}^{-1}$ (component 5, colour code yellow), and calcium carbonate mixed with portlandite (component 5 , light blue).
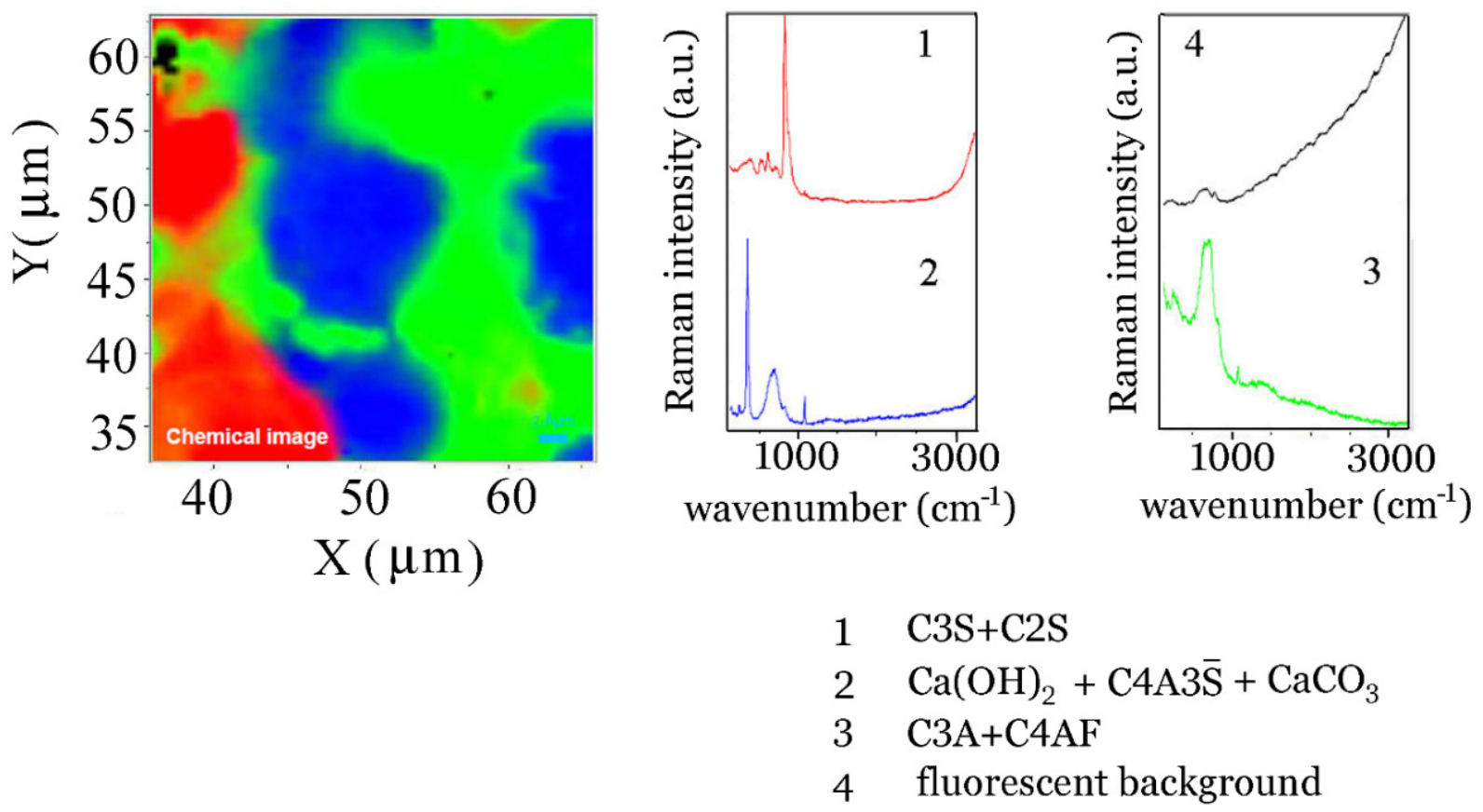

(a)

Figure 5. Cont. 


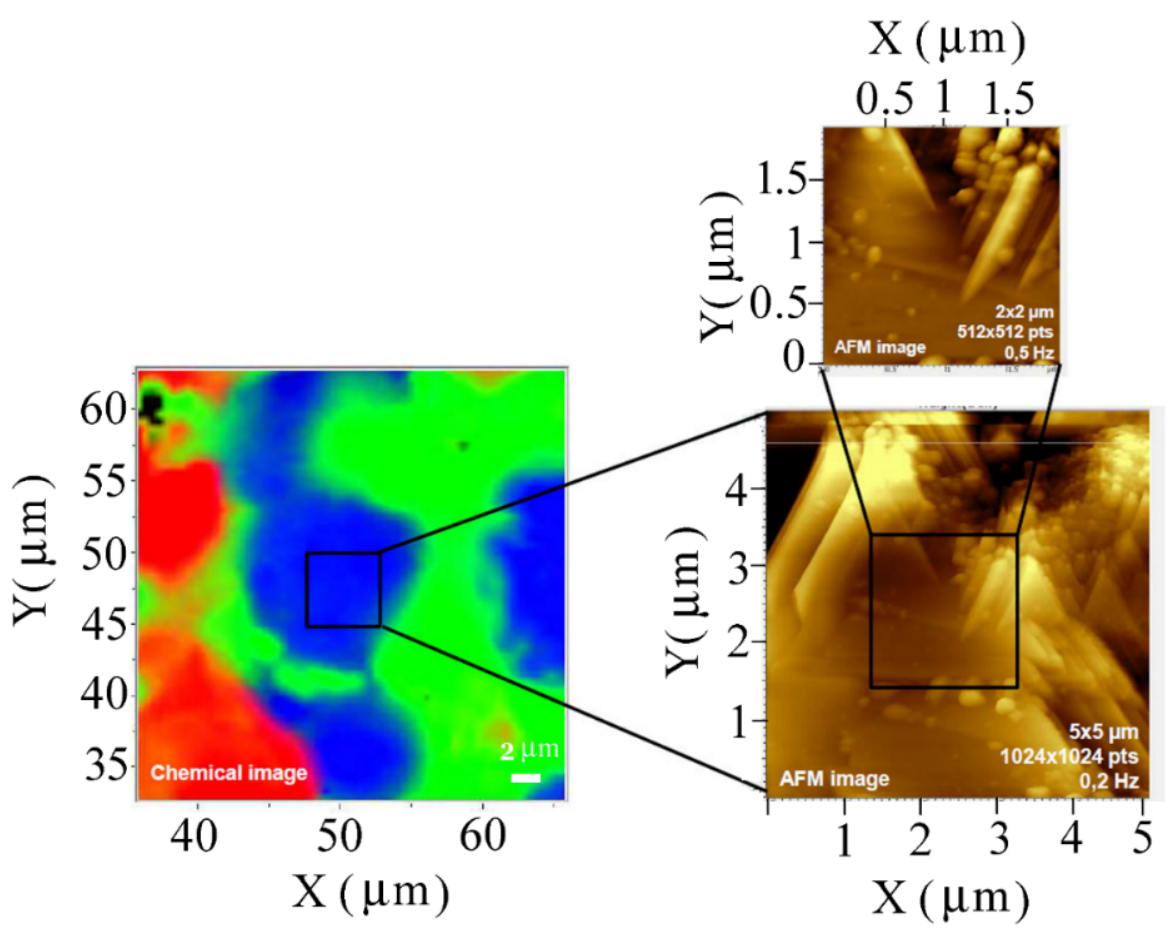

(b)

Figure 5. (a) Colour coded chemical image of clinker 217 obtained using Raman mapping with a HORIBA Jobin-Yvon Labram instrument. Spectra 1 and 4 were offset vertically for clarity. (b). Atomic force micrographs of the selected area of clinker 217 grain from (a). There are spherulites corresponding to amorphous $\mathrm{CaCO}_{3}$ visible on top of the flat surface of portlandite.

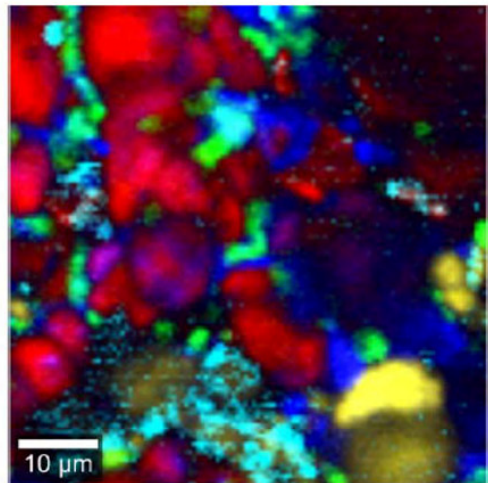

Color coded Raman image.

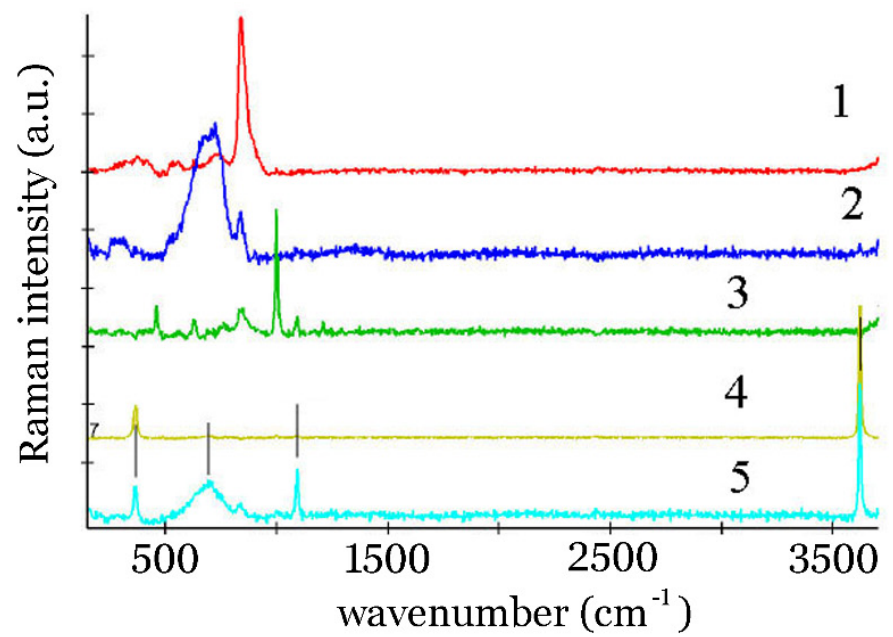

1 alite + belite

$2 \mathrm{C} 3 \mathrm{~A}+\mathrm{C} 4 \mathrm{AF}$

3 gypsum $+\mathrm{C} 4 \mathrm{~A} 3 \overline{\mathrm{S}}$

$4 \mathrm{Ca}(\mathrm{OH})_{2}$

$5 \mathrm{Ca}(\mathrm{OH})_{2}+\mathrm{CaCO}_{3}+\mathrm{C} 3 \mathrm{~A}$

Figure 6. Colour coded Raman image of the 60-micrometer by 60 -micrometer area of the clinker 217 grain. Spectral components given on the right-side result from the software analysis. 
A similar mapping procedure was conducted by Higl et al. while following the hydration of synthetic $\mathrm{m}-\mathrm{C} 3 \mathrm{~S}$ having a water to cement ratio of 0.5 [16]. The five significantly different spectra they identified were m-C3S; $\beta$-C2S; two hydration products, $\mathrm{Ca}(\mathrm{OH})_{2}$ and $\mathrm{C}-\mathrm{S}-\mathrm{H}$; and the fifth component was an unresolved spectrum due to surface roughness. In another study of cement hydration by Torres-Carrasco, the symmetric stretching band of the $\mathrm{SO}_{4}$ group was observed at $996 \mathrm{~cm}^{-1}$ in ettringite shifts to lower wavenumbers on cement hydration, while the $v_{1}\left(\mathrm{SO}_{4}\right)$ of monosulfate rises at $993 \mathrm{~cm}^{-1}$ [14]. Polymerization of silicate chains causes the appearance of additional Si-O stretching bands in Raman spectra, mainly above $1010 \mathrm{~cm}^{-1}$ and below $1050 \mathrm{~cm}^{-1}$ [15]. Infrared spectroscopy has been applied for studying C3S polymorphs as well, but the broadness of the bands and their overlap are significantly greater than in Raman spectra [72]. The limitations of Raman mapping procedure are the simultaneous observation of spectral bands originating from different compounds, which can overlap and complicate the assignment.

\section{Conclusions}

The problem of differentiating similar clinker materials, such as alite and belite, was undertaken by means of Raman spectroscopy and Raman mapping analysis, combined with density functional theory calculations. Raman spectroscopy has been used in the study of dry clinker, ordinary Portland cement, and calcium sulfoaluminate cement and the spectra interpreted by comparison with previous results from the literature and our own calculations of the vibrational density of states performed for crystalline $\beta-\mathrm{Ca}_{2} \mathrm{SiO}_{4}$ and monoclinic $P_{c} \mathrm{Ca}_{3} \mathrm{SiO}_{5}$. The predicted phonon density of states, both for $\mathrm{C} 2 \mathrm{~S}$ and $\mathrm{C} 3 \mathrm{~S}$, displays no vibrational bands in the $560-810 \mathrm{~cm}^{-1}$ interval; therefore, tricalcium aluminate or tetracalcium aluminoferrite can be confidently assigned in that interval. Additionally, crystalline $\beta-\mathrm{Ca}_{2} \mathrm{SiO}_{4}$ has no phonons below $100 \mathrm{~cm}^{-1}$, while crystalline $\mathrm{M}_{1} \mathrm{Ca}_{3} \mathrm{SiO}_{5}$ has the lowest phonon frequency at $27 \mathrm{~cm}^{-1}$. Low frequency Raman spectroscopy could, therefore, be used for a clearer distinction of these two species in a clinker material.

Raman mapping analysis combined with atomic force microscopy provided spatial distribution of different chemical species, requiring no prior chemical preparation of the sample. The limitations of the Raman mapping procedure are the simultaneous observation of spectral bands originating from different compounds, which can overlap and complicate the assignment. It was observed that $\mathrm{Ca}(\mathrm{OH})_{2}$ is often observed together with $\mathrm{CaCO}_{3}$ due to carbonation. Strong bands originating from sulfate groups in gypsum or ye'elimite are observed at 1018 and $993 \mathrm{~cm}^{-1}$, in the spectral interval where symmetric and antisymmetric Si-O stretching bands of silicate tetrahedra are expected in the study of cement hydration.

Supplementary Materials: The following are available online at https:/ /www.mdpi.com/article/10 .3390 / ma14133648/s1, Figure S1: Comparison of Raman spectra of gypsum and Portland cement, Figure S2: Raman spectra of CEM I powder, collected at four different sites. Figure S3: Raman spectrum of polished sample of calcium sulfoaluminate clinker.

Author Contributions: Conceptualization, V.M.-G.; methodology, V.M.-G.; software, A.M.; validation, M.Đ.; investigation, V.M.-G., M.Đ., A.M.; writing-original draft preparation, V.M.-G.; writing-review and editing, V.M.-G., M.Đ., A.M. All authors have read and agreed to the published version of the manuscript.

Funding: This research was funded by THE COMPETITIVENESS AND COHESION OPERATIONAL PROGRAMME BETWEEN CROATIAN GOVERNMENT AND EUROPEAN UNION, grant number KK.01.1.1.01.0001.

Institutional Review Board Statement: Not applicable.

Acknowledgments: Authors acknowledge the kind contribution of HORIBA Jobin-Yvon, Lille, France, and WITec GmbH, Ulm, Germany, for their Raman/AFM measurements of clinker 217.

Conflicts of Interest: The authors declare no conflict of interest. 


\section{References}

1. Đuroković, M. Chemical Resistance of Cement Paste to the Action of Deionized Water. Ph.D. Thesis, University of Zagreb, Zagreb, Croatia, 19 December 2019.

2. Blezard, R.G. The history of calcareous cements. In Lea's Chemistry of Cement and Concrete, 4th ed.; Hewlett, P.C., Ed.; Elsevier: Oxford, UK, 2005; pp. 1-23.

3. The European Cement Association. Activity Report for 2017. Available online: https://cembureau.eu/media/vxyilmsd/activityreport-2017.pdf (accessed on 10 June 2021).

4. Andrew, R.M. Global $\mathrm{CO}_{2}$ emissions from cement production. 1928-2018. Earth Syst. Sci. Data 2019. [CrossRef]

5. Bogue, R.H. Calculation of the Compounds in Portland Cement. Ind. Eng. Chem. Anal. Ed. 1929, 1, 192-197. [CrossRef]

6. Taylor, H.F.W. Cement Chemistry; Thomas Telford: London, UK, 1997.

7. Maki, I.; Fukuda, K.; Yoshida, H.; Kumaki, J. Effect of $\mathrm{MgO}_{\text {and }} \mathrm{SO}_{3}$ on the Impurity Concentration in Alite in Portland Cement Clinker. J. Am. Ceram. Soc. 1992, 75, 3163-3165. [CrossRef]

8. Maki, I.; Goto, K. Factors influencing the phase constitution of alite in portland cement clinker. Cem. Concr. Res. 1982, 12, 301-308. [CrossRef]

9. Barnes, P.; Fentiman, C.H.; Jeffery, J.W. Structurally related dicalcium silicate phases. Acta Crystallogr. Sect. A 1980, 36, 353-356. [CrossRef]

10. Barcelo, L.; Kline, J.; Walenta, G.; Gartner, E. Cement and carbon emissions. Mater. Struct. 2013, 47, 1055-1065. [CrossRef]

11. Aranda, M.A.G.; Dela Torre, A.G. Sulfoaluminate cements. In Eco-Efficient Concrete; Pacheo-Torgal, F., Jalali, S., Labrinda, J., Eds.; Woodhead Publishing Limited: Cambridge, UK, 2013; pp. 488-522.

12. Pellenq, R.J.-M.; Lequeux, N.; van Damme, H. Engineering the bonding scheme in C-S-H: The iono-covalent framework. Cem. Concr. Res. 2008, 38, 159-174. [CrossRef]

13. Peled, A.; Castro, J.; Weiss, W. Atomic force and lateral force microscopy (AFM and LFM) examinations of cement and cement hydration products. Cem. Concr. Compos. 2013, 36, 48-55. [CrossRef]

14. Torres-Carasco, M.; del Campo, A.; de la Rubia, M.A.; Reyes, E.; Moragues, A.; Fernáández, J.F. In situ full view of Portland cement hydration by confocal Raman microscopy. J. Raman Spectrosc. 2019, 50, 720-730. [CrossRef]

15. Ortaboy, S.; Li, J.; Geng, G.; Myers, R.J.; Monteiro, P.J.M.; Maboudian, R.; Carraro, C. Effects of $\mathrm{CO}_{2}$ and temperature on the structure and chemistry of C-(A-)S-H investigated by Raman spectroscopy. RSC Adv. 2017, 7, 48925-48933. [CrossRef]

16. Higl, J.; Köhler, M.; Lindén, M. Confocal Raman microscopy as a non-destructive tool to study microstructure of hydrating cementitious materials. Cem. Concr. Res. 2016, 88, 136-143. [CrossRef]

17. Liu, F.; Sun, Z.; Qi, C. Raman spectroscopy study on the hydration behaviours of Portland cement pastes during setting. J. Mater. Civ. Eng. 2015, 27, 04014223. [CrossRef]

18. Bullard, J. MicroChar: An application for quantitative analysis of cement and clinker microstructure images. In MicroChar: An Application for Quantitative Analysis of Cement and Clinker Microstructure Images; National Institute of Standards and Technology: Gaithersburg, MD, USA, 2015. [CrossRef]

19. Thiery, V.; Slomianny, C.; Serris, E. From light and drawings to electrons and X-rays: A primer of Portland cement clinker microscopy. Microsc. Anal. 2016, 29, 17-22.

20. Trtik, P.; Kaufmann, J.; Volz, U. On the use of peak-force tapping atomic force microscopy for quantification of the local elastic modulus in hardened cement paste. Cem. Concr. Res. 2012, 42, 215-221. [CrossRef]

21. Lomboy, G.; Sundararajan, S.; Wang, K.; Subramaniam, S. A test method for determining adhesion forces and Hamaker constants of cementitious materials using atomic force microscopy. Cem. Concr. Res. 2011, 41, 1157-1166. [CrossRef]

22. Dawson, P.; Hadfield, C.; Wilkinson, G. The polarized infra-red and Raman spectra of $\mathrm{Mg}(\mathrm{OH})_{2}$ and Ca(OH $)_{2}$. J. Phys. Chem. Solids 1973, 34, 1217-1225. [CrossRef]

23. Buchanan, R.A.; Caspers, H.H.; Murphy, J.; Buchanan, R.A.; Caspers, H.H.; Murphy, J. Lattice Vibration $\mathrm{Spectra}$ of $\mathrm{Mg}(\mathrm{OH})_{2}$ and $\mathrm{Ca}(\mathrm{OH})_{2}$. Appl. Opt. 1963, 2, 1147-1150. [CrossRef]

24. Oehler, O.; Günthard, H.H. Ca(OH $)_{2}$ and $\mathrm{Ca}(\mathrm{OD})_{2}$ vibrational crystal spectra, normal coordinate analysis, and assignment. J. Chem. Phys. 1968, 48, 2036-2045. [CrossRef]

25. RRUF Mineral Database. Available online: https:/ / rruff.info./portlandite/display=default/ (accessed on 29 June 2021).

26. Voisin, M.; Mon, J.P. Spectre Raman de l'oxyde de calcium. Phys. Status Solidi B 1971, 48, K185-K187. [CrossRef]

27. Rieder, K.H.; Weinstein, B.A.; Cardona, M.; Bilz, H. Measurement and Comparative Analysis of the Second-Order Raman Spectra of the Alkaline-Earth Oxides with a NaCl Structure. Phys. Rev. B 1973, 8, 4780-4786. [CrossRef]

28. Martinez-Ramirez, S.; Sanchez-Cortes, S.; Garcia-Ramos, J.; Domingo, C.; Fortes, C.; Blanco-Varela, M.T. Micro-Raman spectroscopy applied to depth profiles of carbonates formed in lime mortar. Cem. Concr. Res. 2003, 33, 2063-2068. [CrossRef]

29. López-Arce, P.; Gómez-Villalba, L.; Martinez-Ramirez, S.; Álvarez de Buergo, M.; Fort, R. Influence of relative humidity on the carbonation of calcium hydroxide nanoparticles and the formation of calcium carbonate polymorphs. Powder Technol. 2011, 205, 263-269. [CrossRef]

30. Dubina, E.; Korat, L.; Black, L.; Strupi-Šuput, J.; Plank, J. Influence of water vapour and carbon dioxide on free lime during storage at $80^{\circ} \mathrm{C}$ studied by Raman spectroscopy. Spectrochim. Acta Part A Mol. Biomol. Spectrosc. 2013, 111, 299-303. [CrossRef] [PubMed]

31. Schmid, T.; Dariz, P. Shedding light onto the spectra of lime: Raman and luminescence bands of $\mathrm{CaO}, \mathrm{Ca}(\mathrm{OH})_{2}$ and $\mathrm{CaCO} 2 . J$. Raman Spectrosc. 2015, 46, 141-146. [CrossRef] 
32. Kaszowska, Z.; Malek, K.; Staniszewska-Slezak, E.; Niedzielska, K. Raman scattering of fluorescence emission? Raman spectroscopy study on lime. Spectrochim. Acta Part A Mol. Biomol. Spectrosc. 2016, 169, 7-15. [CrossRef]

33. Martínez-Ramírez, S.; Fernández-Carrasco, L. Raman spectroscopy: Application to cementitious systems. In Construction and Building: Design, Materials and Techniques; Doyle, S.G., Ed.; Nova Science Publishers, Inc.: New York, NY, USA, 2011 ; pp. $233-244$.

34. Bensted, J. Uses of Raman Spectroscopy in Cement Chemistry. J. Am. Ceram. Soc. 1976, 59, 140-143. [CrossRef]

35. Bensted, J. Raman spectral studies of carbonation phenomena. Cem. Concr. Res. 1977, 7, 161-164. [CrossRef]

36. Krishnamurthy, N.; Soots, V. Raman Spectrum of Gypsum. Can. J. Phys. 1971, 49, 885-896. [CrossRef]

37. Conjeaud, M.; Boyer, H. Some possibilities of Raman microprobe in cement chemistry. Cem. Concr. Res. 1980, 10, 61-70. [CrossRef]

38. Handke, M. Vibrational Spectra, Force Constants, and Si-O Bond Character in Calcium Silicate Crystal Structure. Appl. Spectrosc. 1986, 40, 871-877. [CrossRef]

39. Ibáñez-Insa, J.; Artús, L.; Cuscó, R.; López, Á.; Menéndez, E.; Andrade, M.C. Hydration and carbonation of monoclinic C2S and C3S studied by Raman spectroscopy. J. Raman Spectrosc. 2006, 38, 61-67. [CrossRef]

40. Garg, N.; Wang, K. Applying Raman spectroscopy for studying cement-based materials. In Microstructural-Related Durability of Cementitious Composites; Ye, G., Van Breugel, K., Sun, W., Miao, C., Eds.; RILEM Publications SARL: Amsterdam, The Netherlands, 2012; pp. 275-282.

41. Dyer, C.D.; Hendra, P.J.; Forsling, W. The Raman spectroscopy of cement minerals under 1064 nm excitation. Spectrochim. Acta Part A Mol. Spectrosc. 1993, 49, 715-722. [CrossRef]

42. Bonen, D.; Johnson, T.; Sarkar, S. Characterization of principal clinker minerals by FT-Raman microspectroscopy. Cem. Concr. Res. 1994, 24, 959-965. [CrossRef]

43. Aminzadeh, A. Fluorescence bands in the FT-Raman spectra of some calcium minerals. Spectrochim. Acta Part A Mol. Biomol. Spectrosc. 1997, 53, 693-697. [CrossRef]

44. Newman, S.P.; Clifford, S.J.; Coveney, P.V.; Gupta, V.; Blanchard, J.D.; Serafin, F.; Ben-Amotz, R.; Diamond, S. Anomalous fluorescence in near-infrared Raman spectroscopy of cementitious materials. Cem. Concr. Res. 2005, 35, 1620-1628. [CrossRef]

45. Schootmans, E.M.J.; Wilson, A.J.; Brettell, R.; Munshi, T.; Edwards, H.G.M. Raman spectroscopy as a non-destructive screen technique for studying white substances from archeological and forensic burial contexts. J. Raman Sectrosc. 2014, 45, 1301-1308. [CrossRef]

46. Potgieter-Vermaak, S.; Potgieter, J.H.; Van Grieken, R. The application of Raman spectrometry to investigate and characterize cement, Part I: A review. Cem. Concr. Res. 2006, 36, 656-662. [CrossRef]

47. Skibsted, J.; Hall, C. Characterization of cement minerals, cements and their reaction products at the atomic and nano scale. Cem. Concr. Res. 2008, 38, 205-225. [CrossRef]

48. Black, L. Raman spectroscopy of cementitious materials. Spectrosc. Prop. Inorg. Organomet. Compd. 2009, 40, 72-127. [CrossRef]

49. Jost, K.H.; Ziemer, B.; Seydel, R. Redetermination of the structure of $\beta$-dicalcium silicate. Acta Crystallogr. Sect. B Struct. Crystallogr. Cryst. Chem. 1977, 33, 1696-1700. [CrossRef]

50. De Noirfontaine, M.-N.; Dunstetter, F.; Courtial, M.; Gasecki, G.; Signes-Frehel, M. Polymorphism of tricalcium silicate, the major compound of Portland cement clinker: Modelling alite for Rietveld analysis, an industrial challenge. Cem. Concr. Res. 2006, 36, 54-64. [CrossRef]

51. Dunstetter, F.; de Noirfontaine, M.-N.; Courtial, M. Polymorphism of tricalcium silicate, the major compound of Portland cement clinker: Structural data: Review and unified analysis. Cem. Concr. Res. 2006, 36, 39-53. [CrossRef]

52. Courtial, M.; De Noirfontaine, M.-N.; Dunstetter, F.; Gasecki, G.; Signes-Frehel, M. Polymorphism of tricalcium silicate in Portland cement: A fast visual identification of structure and superstructure. Powder Diffr. 2003, 18, 7-15. [CrossRef]

53. Dovesi, R.; Orlando, R.; Civalleri, B.; Roetti, C.; Saunders, V.R.; Zicovich-Wilson, C. CRYSTAL: A computational tool for the ab initio study of the electronic properties of crystals. Z. Krist. Cryst. Mater. 2005, 220, 571-573. [CrossRef]

54. Valenzano, L.; Torres, F.J.; Doll, K.; Pascale, F.; Zicovich-Wilson, C.M.; Dovesi, R. Ab Initio Study of the Vibrational Spectrum and Related Properties of Crystalline Compounds; the Case of $\mathrm{CaCO}_{3}$ Calcite. Z. Phys. Chem. 2006, 220, 893-912. [CrossRef]

55. Pascale, F.; Zicovich-Wilson, C.; Orlando, R.; Roetti, C.; Ugliengo, P.; Dovesi, R. Vibration Frequencies of $\mathrm{Mg}_{3} \mathrm{Al}_{2} \mathrm{Si}_{3} \mathrm{O}_{12} \mathrm{Pyrope}$ An ab Initio Study with the CRYSTAL Code. J. Phys. Chem. B 2005, 109, 6146-6152. [CrossRef] [PubMed]

56. Noel, Y.; Catti, M.; D'Arco, P.; Dovesi, R. The vibrational frequencies of forsterite $\mathrm{Mg}_{2} \mathrm{SiO}_{4}$ : An all-electron ab initio study with the CRYSTAL code. Phys. Chem. Miner. 2006, 33, 383-393. [CrossRef]

57. Vosko, S.H.; Wilk, L.; Nusair, M. Accurate spin-dependent electron liquid correlation energies for local spin density calculations: A critical analysis. Can. J. Phys. 1980, 58, 1200-1211. [CrossRef]

58. Dirac, P.A.M. Note on the Exchange in Thomas Atom. Proc. Camb. Philos. Soc. 1930, 26, 376-385. [CrossRef]

59. Mitchell, R.S. Note on a single-crystal x-ray study of calcium hydroxide. Z. Krist. 1966, 123, 272-273. [CrossRef]

60. Baranek, P.; Lichanot, A.; Orlando, R.; Dovesi, R. Structural and vibrational properties of solid $\mathrm{Mg}(\mathrm{OH})_{2}$ and $\mathrm{Ca}(\mathrm{OH})_{2}-$ Performances of various hamiltonians. Chem. Phys. Lett. 2001, 340, 362-369. [CrossRef]

61. Perdew, J.P.; Wang, J. Accurate and simple density functional for the electronic exchange energy: Generalized gradient approximation. Phys. Rev. B 1986, 33, 8800-8802. [CrossRef] [PubMed]

62. Perdew, J.P.; Wang, Y. ERRATUM-Accurate and simple density functional for the electronic exchange energy: Generalized gradient approximation. Phys. Rev. B 1989, 40, 3399. [CrossRef]

63. Perdew, J.P.; Wang, Y. Accurate and simple analytic representation of the electron-gas correlation energy. Phys. Rev. B 1992, 45, 13244-13249. [CrossRef] 
64. Perdew, J.P. Electronic structure of solids '91. In Proceedings of the 75 WE-Heraeus-Seminar and 21st Annual International Symposium on Electronic Structure of Solids, Gaussig, Germany, 11-15 March 1991; Akademie Verlag: Berlin, Germany, 1991; p. 11.

65. Becke, A.D. Density-functional thermochemistry. III. The role of exact exchange. J. Chem. Phys. 1993, 98, 5648-5652. [CrossRef]

66. Lee, C.; Yang, W.; Parr, R.G. Development of the Colle-Salvetti correlation-energy formula into a functional of the electron density. Phys. Rev. B 1988, 37, 785-789. [CrossRef]

67. Manzano, H.; Pellenq, R.J.M.; Ulm, F.-J.; Beuhler, M.J.; Van Duin, A.C.T. Hydration ofcalcium oxide surface predicted by reactive force field molecular dynamics. Langmuir 2012, 28, 4187-4197. [CrossRef]

68. Perdew, J.P.; Burke, K.; Ernzerhof, M. Generalized gradient approximation made simple. Phys. Rev. Lett. 1996, 77, 3865-3868. [CrossRef]

69. Nishi, F.; Takeuchi, Y.; Maki, I. Tricalcium Silicate $\mathrm{Ca}_{3} \mathrm{O}\left[\mathrm{SIO}_{4}\right]$ : The monoclinic superstructure. Z. Krist. Cryst. Mater. 1985, 172, 297-314. [CrossRef]

70. CRYSPLOT Website. Available online: http:// crysplot.crystalsolutions.eu/web_pages_yves3/vibration.html (accessed on 10 June 2021).

71. Tlili, M.M.; Ben Amor, M.; Gabrielli, C.; Joiret, S.; Maurin, G.; Rousseau, P. Characterization of CaCO 3 hydrates by micro-Raman spectroscopy. J. Raman Spectrosc. 2002, 33, 10-16. [CrossRef]

72. Ren, X.; Zhang, W.; Ye, J. FTIR study on the polymorphic structure of tricalcium silicate. Cem. Concr. Res. 2017, 99, 129-136. [CrossRef] 